American Journal of Pharmaceutical Education 2011; 75 (1) Article 19.

LEGACY ARTICLES

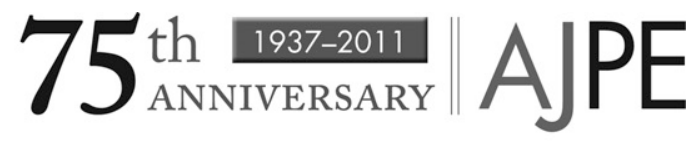

\title{
THE EDITOR'S PAGE
}

\author{
Rufus A. Lyman
}

You are now reading the anlage of the American Journal of Pharmaceutical Education. It came about in this way. For a long time there has been a feeling that the Proceedings did not satisfy the needs of the American Association of Colleges of Pharmacy. I suppose this happens in the life of every organization. Well do I remember back in 1912 when it happened to the American Pharmaceutical Association. The activities of that organization became so numerous and so diversified that some other means of communication than the Proceedings was needed. The Journal was born. Pharmaceutical education has come to be one of the major fields of professional education. We have not only been asked to contribute something creative to the field of professional education, but we are expected to contribute our share to the field of general education, on all its levels, as well. Such service cannot be rendered by meeting together and thinking together once a year. The journal will enable us to do that four times a year and let us hope that in the not too distant future, it may be still more frequent.

This is how it happened. At the Dallas meeting last fall, the Association expressed its opinion in no uncertain terms, that the time had come for the establishment of a journal devoted exclusively to the problems of pharmaceutical education and administration. The Association left the whole matter in the hands of the Executive Committee with power to act. The Executive Committee appointed a subcommittee consisting of Ernest Little, Charles B. Jordan and Rufus A. Lyman, Chairman, to work out all necessary details in connection with the establishment of a journal. This committee functioned and about the middle of December it was decided to proceed with the publication of the journal, the entire Executive Committee to act as a publication board with Rufus A. Lyman as Chairman and Editor. It was further decided to retain the Association's department in the Journal of the American Pharmaceutical Association under the control of the Publication Board.

Following the instructions of the Board, the Editor has asked the dean of each member college to nominate some member of his faculty to act as an associate editor, or collaborator. 
American Journal of Pharmaceutical Education 2011; 75 (1) Article 19.

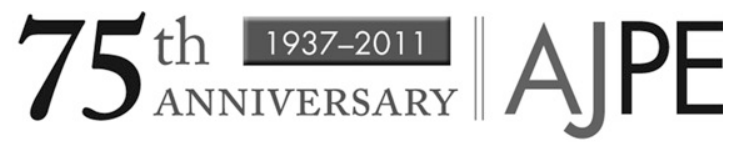

The Editor looked up the meaning of the words collaborate and collaborator in the dictionary. When he found the verb means, "to labor together" and the noun means, "one who collaborates," he immediately chose to designate the workers as Collaborators. The function of the Collaborators will be to do everything that is necessary to be done, from the gathering of news and the obtaining of, or writing, of worthwhile contributions and editorials, to the collecting of subscriptions. Details will be taken up with the Collaborators personally. The name of each Collaborator, as soon as appointed, will appear in each issue of the Journal. As the editor read over the list of Collaborators he was struck by the number of names that were new to him. These names can only be a fraction of the host of young men yet unknown in a national way, that are engaged in pharmaceutical education. The possibilities in this group are grand to contemplate. And what a camaraderies they have ahead of them in this work!

The question arises as to what shall be printed in the Journal. From a necessity which is obvious, the material in the first two or three numbers must be determined by the Editor. He has ideas. Certainly the papers given at the annual meetings and teachers conferences, together with a summary of proceedings and committee reports should appear in due time. Editorials on the live problems of the day and announcements of scientific programs, such as that of $\left(\mathrm{N}_{2}\right)$ Subsection on Pharmacy of the American Association for the Advancement of Science, have a place. These scientific papers, however, must find a place for publication elsewhere as this is not a scientific journal, only in so far as scientific principles and methods are applied in the solving of problems of pharmaceutical education and administration. As to news, only such items will be published that the Editor considers may be of general interest. In other words, news items must have more than a local interest. The Editor will always weigh the material presented in the light as to whether it is worth two dollars and thirty cents a page (the present cost of publication) to the cause of pharmaceutical education. These are only suggestions which the Editor has made primarily for his own guidance until such a time as the Association may be more specific in the conduct of the Journal. This is your journal and the Editor will welcome the severest criticism from the appearance of the very first number. 
American Journal of Pharmaceutical Education 2011; 75 (1) Article 19.

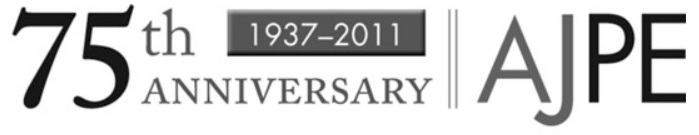

The question who shall receive free copies of the American Journal of Pharmaceutical Education has not been determined. One copy of course will be sent to the library of each member college. It undoubtedly should be sent to other libraries, both domestic and foreign, where the Proceedings have formerly been sent. For the first year the major part of the cost of publication can be paid out of our income, as the cost of the Proceedings have been. It should be understood that neither the Editor nor anyone connected with the production of the Journal receives any compensation. This is a labor of love-we hope, with men of vision. The Editor under date of January 25, 1937, mailed his personal check for two dollars to Professor Zada M. Cooper, of the University of Iowa, and hopes thereby to go down in history as subscriber number I, to the American Journal of Pharmaceutical Education. May many follow after.

On another page is the program and a brief abstract of the program of the pharmacy section given at the Atlantic City meeting of the American Association for the Advancement of Science in December. This program is serving a real purpose in giving pharmacy a position among the creative sciences. Dr. John C. Krantz is doing an excellent piece of work in building these programs. He is already calling for papers for the Denver meeting next June. This is an opportunity for our research workers in the Rocky Mountain region and for those who spend their vacation there, to produce a good program.

The University of Oklahoma and the Philadelphia College of Pharmacy and Science are to be commended for the popular programs they are sponsoring. These programs present in a dignified way the public service the pharmacist renders.

In his presidential address, printed in the current issue, Dean Robert C. Wilson left the well beaten path along which we have been plodding for a third of a century and struck out into the realm of things spiritual. Not once did he mention brick and mortar, office, laboratory, or lecture room, equipment, library, or the number of men on the staff. Far above these things he soared and dwelt upon the spiritual perfection that must be attained by teacher and pupil if pharmacy is to take its proper place in the world as a profession of service. All thoughtful men know he is right, but to fully appreciate his attitude requires the spending of at least one day in northern Georgia as I did in May, 1936. 
American Journal of Pharmaceutical Education 2011; 75 (1) Article 19.

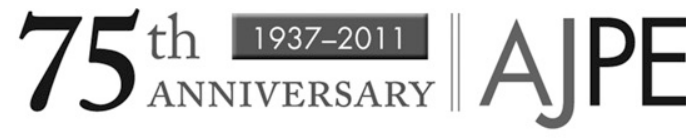

The Wilson car stopped at the curb in the village of Jefferson a few minutes run from Athens. I found myself standing in front of a house showing signs of decay in spite of apparent heroic efforts to save it. In a room in this house Crawford W. Long discovered how to give humanity relief from pain and made the triumphs of modern surgery possible. I found my hat in my hand. Certainly a crumbling building did not cause me to remove it. No hat could stay on a man's head at the scene of that humanitarian accomplishment.

A few miles farther on the car again stopped and I found myself bare headed before a dilapidated old farm house. The yard was strewn with wornout farm tools; pigs were sleeping in the shade of the crumbling foundation. Near by in a weed covered burial lot I found a broken slab of stone still protecting a grave. On the surface was carved the name and date, William Harris Crawford-1772-1834. Crawford was a friend of President Monroe and Secretary of the Treasury in his Cabinet and within the crumbling walls of that old house, Monroe had penned the Monroe Doctrine.

The car rolled on. Mansion after mansion we passed, each having stately pillars that would have done credit to an Athenian temple. Now all of them are in a state of decay and the marvelous boxwood gardens that once surrounded them have been torn up to enhance the beauty of a distant city. It required no flight of imagination to feel the friendship and hospitality of those plantation homes in plantation days, for those qualities still remain the prized possessions of the people of Georgia.

The material things I saw that day belong to another age. They are gone with the wind. But the spiritual things live on, a blessing to humanity. Robert C. Wilson is a product of that civilization. He could rise above these decaying things about him and bring us a message of the value of things spiritual. Only spiritual things are eternal.

Dr. Lotus D. Coffman, President of the University of Minnesota has been one of our severest critics for trying to determine the efficiency of our colleges by the use of a yardstick. Once he said to the writer "Why don't you do something for the intellectual and spiritual growth of your faculties?" I think if President Coffman could have heard Doctor Wilson read his address, he would have remarked, "Now, Gentlemen, you are on the right track." 